\title{
The Identic Turn: The Culpability of Accessories and Perpetrators
}

\author{
Penny Crofts
}

This article analyses the legal concept of wickedness through the 16th century case of Saunders and its representations by treatise writers. Saunders had tried to kill his wife by giving her a poisoned apple. Not knowing it was poisoned, his wife gave the apple to their daughter, who died. Saunders was charged with murder but argued that he did not have malice against his daughter, and therefore should not be found guilty. Treatise writers drew upon different sources to construct a persuasive model of legal wickedness including evil intention, harmful consequences, manifest criminality, and the religious imagery of the apple. Saunders is a reminder of alternative models of legal wickedness that have been neglected.

\section{INTRODUCTION}

John Saunders had a wife whom he intended to kill, in order that he might marry another woman with whom he was in love, and he opened his design to ... Alexander Archer, and desired his assistance and advice in the execution of it, who advised him to put an end to her life by poison. With this intent the said Archer bought the poison, viz. arsenick and roseacre, and delivered it to the said John Saunders to give it to his wife, and accordingly gave it to her, being sick, in a roasted apple, and she eat a small part of $i$, and gave the rest to the said Eleanor Saunders, an infant, about three years of age, who was the daughter of her and the said John Saunders her husband. And the said John Saunders seeing it, blamed his wife for it, and said that apples were not good for such infants; to which his wife replied that they were better for such infants than for herself; and the daughter eat the poisoned apple, and the said John Saunders, her father, saw her eat it, and did not offer to take it from her lest he should be suspected, and afterwards his wife recovered, and the daughter died of the said poison.

And whether or not this was murder in John Saunders, the father, was somewhat doubted, for he had no intent to poison his daughter, nor had he any malice against her, but on the contrary he had a great affection for her, and he did not give her any poison, but his wife ignorantly gave it her ...

But the most difficult point in this case, and upon which the justices conceived greater doubt than the offence of the principal, was, whether or no Archer should be adjudged accessory to the murder. ${ }^{1}$

Saunders was found guilty of the murder of Eleanor and put to death. ${ }^{2}$ Archer provided assistance for the murder of Saunders' wife, but the

$1 \quad R v$ Saunders and Archer (1573) 2 Plowden 473; 75 ER 706, 707. Henceforth the case will be referred to as Saunders and Archer in the text.

2 For an analysis of Saunders' culpability see Penny Crofts, Wickedness and Crime: Laws of homicide and malice (Routledge, 2013). 
judges were undecided as to whether he was liable for Saunders' murder of his daughter. Was Archer responsible for the death of Eleanor, or did the fact that Saunders killed the wrong victim exculpate Archer, and, if so, how? The judges in Saunders and Archer responded to the conundrum by suspending judgment: 'For the offence which Archer committed was the aid and advice which he gave to Saunders, and that was only to kill his wife, and no other'. ${ }^{3}$ The judges thought it 'proper to advise and consider of it until the next gaol delivery, and in the meantime to consult with the justices in the term ... And at the next gaol-delivery the matter was respited until the next time afterwards, and so from session to session until this present term of St Hillary, anno 1575'. During the time of consideration Archer was kept in the custody of the sheriff, 'there to tarry and be safely kept'. Finally, the judges agreed:

[T] hat they ought not to give judgment against the said Alexander Archer, because they took the law to be that he could not be adjudged accessory to the said offence of murder, for that he did not assent that the daughter should be poisoned, but only that the wife should be poisoned, which assent cannot be drawn further than he gave for it, for the poisoning of the daughter is a distinct thing from that to which he was privy, and therefore he shall not be adjudged accessory to it; and so they were resolved before this time. And although they were agreed, yet, rather than make a precedent of it, they reprieved him from one session to another for divers sessions, to the intent that he might purchase his pardon, and by that means be set at liberty. ${ }^{4}$

Plowden's report of Saunders and Archer communicates the quandary of the judges. ${ }^{5}$ This was a case of a 'doubtful or delicate nature'. ${ }^{6}$ Under existing principles, Archer should either have been subject to the same punishment as Saunders (that is, death), or he should have been free from all liability. Whilst the judges pondered, Archer was kept in the custody of the sheriff, so the process and delay of judgment was itself a form of punishment. Instead of acquitting Archer outright, the judges required that he purchase a pardon. This approach by the judges was exceptional

$3 \quad R v$ Saunders and Archer (1573) 2 Plowden 473; 75 ER 706, 709.

4 Ibid.

$5 \quad$ The Queen $v$ Saunders and Archer (1573) 2 Plowden 473; 75 ER 706 was reported in The Commentaries or Reports of Edmund Plowden, of the Middle-Temple Esq. An Apprentice of the Common Law: Containing Divers Cases upon Matters of Law, argued and adjudged in the several reigns of King Edward VI, Queen Mary, King and Queen Philip and Mary, and Queen Elizabeth. To which are added the Quaeries of Mr Plowden. In Two Parts. Plowden is regarded as the first 'modern writer' of case reports. His were the first set of reports prepared for publication during his lifetime, and Plowden's own cases were being cited within a year of being printed. See Karen Cunningham, Imaginary Betrayals: subjectivity and the discourse of betrayal in early modern England (University of Pennsylvania, 2002).

6 Michael Foster, A Report of Some Proceedings on the Commission of Oyer and Terminer and Goal Delivery for the Trial of the rebels in the Year 1746 in the County of Surry, and of Other Crown Cases. To which are added discourses upon a few branches of the Crown Law (London, first published 1762, 1982 ed), 371. 
- the purchasing of a pardon was available procedurally for excusable homicides, ${ }^{7}$ but this was not a case of excusable homicide. Detaining Archer until he purchased a pardon, despite acquittal, expressed a recognition by the judges of the complexity of judging Archer's culpability. The key question this article explores is: why was Archer's culpability so difficult to judge? This is more than a legal historical analysis, as the questions of culpability raised in Archer's case continue to be unresolved in contemporary common legal doctrine. ${ }^{8}$ The common law elements of complicity remain the same in contemporary law as those in Archer's time. Moreover, the assumptions of derivative liability continue to underlie contemporary complicity doctrine. Through a close analysis of the issues raised by Archer's case, this article provides insight into, but does not resolve, doubts and queries about the historical and contemporary legal doctrine of complicity.

Historically and currently, the common law rules of accessorial liability have generated a jurisprudence of blaming that is inconsistent and incoherent. Professor Ashworth has described the law as:

$[R]$ eplete with uncertainties and conflict. It betrays the worst features of the common law: what some would regard as flexibility appears here as a succession of opportunistic decisions by the courts, often extending the law, and resulting in a body of jurisprudence that has little coherence. ${ }^{9}$

The common law has had difficulty in identifying and articulating the substance of the culpability of accessories. These difficulties have been reiterated and reinforced by a lack of clarity in language, and a repetition and absence of resolution of doctrinally challenging cases. I will explore the ways in which the complexity of this area of legal doctrine was aided and abetted by the identic turn through an analysis of the case of Saunders and Archer and of treatise writers between the 16th and 18th centuries.

The word identic emerged in the 17th century from Medieval Latin identicus 'the same', from Late Latin identitas 'identity, sameness'. From

$7 \quad$ Naomi Hurnard, The King's Pardon for Homicide (Oxford University Press, 1969), ch 1. Excusable homicide did not result in outright acquittal. Rather, the slayer was required to obtain a royal pardon, which absolved them of the liability to royal suit, but left open the right of the victim's kin to prosecute or appeal.

8 A modern equivalent of The Queen $v$ Saunders and Archer (1573) 2 Plowden 473; 75 ER 706 is $R v$ Longone [1938] SALR (AD) 532. In that case, L supplied poison to $\mathrm{C}$ to enable $\mathrm{C}$ to poison his wife. $\mathrm{C}$ poisoned the drinking water in the hut usually occupied by his wife, but $\mathrm{C}$ discovered the hut would be occupied by $\mathrm{V}$ and another. For fear of self-incrimination, C did nothing, permitting $\mathrm{V}$ fatally to drink the poisoned water. $\mathrm{L}$ was acquitted. It was held that he was liable only for acts authorised by him and such steps that 'he should have reasonably contemplated, or foreseen as likely to be taken by the principal and what occurred ... was not a reasonable probability which should have been foreseen by the principal'. But Tindall and de Wet JJA imply acquittal was due to C's failure to intervene to prevent the plan miscarrying, so converting C's behaviour into the equivalent of voluntary deviation.

9 Andrew Ashworth, Principles of Criminal Law (Oxford University Press, 2003) 441. 
the 1630 s it had the general sense of 'being the same or very similar'. This article explores the identic turn in the doctrine of complicity. For the purposes of this article, the identic turn is the treatment by the courts and legal doctrine of accessories as identic to principals. The identic turn can be analysed in terms of procedural and substantive law and underlying patterns of blameworthiness. There is no specific point of origin of the identic turn. The culpability of accessories was (and is) derivative upon the culpability of perpetrators, and accessories were liable to the same charges and punishment as the perpetrator. From the 16th century onwards, the courts treated accessories as 'being the same or very similar' to the perpetrator of the crime - 'all persons present aiding and abetting are principals' ${ }^{10}$ Problems for the judiciary and treatise writers of articulating and justifying blameworthiness were based upon identifying not only commonalities, but also explaining where the subtle differences lay in the 'same or very similar'. The lack of a coherent story about the fault or blame of accessories due to the unspoken premise of the nature of complicity's relationship with principal liability is captured in the question of the identic turn. How similar are accomplices to principals, and to what extent can and should the law regard accomplices as the same as principals? In terms of my case study, could and should Archer's liability be identic with the liability and punishment of Saunders?

Whilst difficulties in the doctrine of complicity can be regarded as specific to historical periods, contemporary doctrine highlights that these difficulties are perennial. Thus, the question of Archer's guilt or its absence still does not have a straightforward answer. In Part Two, I consider the procedural history of complicity evolving at the time of Saunders, whereby accessories could be tried and liable to the same punishment as principal perpetrators. I argue that this procedural identic turn was not accompanied by a clear articulation or justification of the liability of accessories. The history of the procedural identic turn rested upon, and was reinforced by, an absence of clearly articulated justifications for culpability for complicity. Archer's case highlights the way that the implicit appeal of accessorial liability does not provide the boundaries or justifications for culpability. In Part Three, I demonstrate the ways in which the doctrine of complicity challenged and challenges key legal doctrinal assumptions of agency and autonomy in attributions of blameworthiness. A shadow or parasitic form of liability was (and is) assumed and applied to accessories - their liability was (and is) dependent upon the acts of another. My analysis shows the difficulties in applying traditional models of blameworthiness to accessories. The unresolved and forgotten story of Archer's culpability is unsatisfying, and remains incomplete and unresolved in contemporary criminal law. 


\section{The Identic Turn: Procedural History and Questions of CulPability}

The substantive law of complicity is imbricated with a complex procedural history, described as 'tortured'11 and heavily laced up with 'Cobweb Lawes'. ${ }^{12}$ Saunders and Archer was heard at a time that the procedure of accessories was evolving. The history reveals an absence of differentiation in moral or fault terms, and instead piecemeal responses to procedural impediments with substantive consequences that haunt modern law today. ${ }^{13}$ It is a history of a procedural identic turn - accomplices were to be treated the same as principals. Accessories could be tried prior to the principal's trial and conviction and were deemed liable to the same punishment as a principal in the first degree. Although through procedural reforms accessories were (and are) treated the same, I argue in the next part the underlying patterns of blameworthiness for principals could (and can) not be easily applied to accessories.

From the 13th century onwards, the common law developed a strict rule that an accessory to a felony could not be convicted unless there was proof that the perpetrator had been convicted and suffered punishment by way of 'attainder', that is, sentence of death. ${ }^{14}$ That is, the ability to try and convict accomplices was dependent on the principal being convicted:

If the principall be convict by verdict and prayeth his clergie; or if the principall upon his arraignement confesse the felonies, and before judgement obtaine a pardone the accessarie is thereby discharged ... and so it is if the principall dies before judgement, or upon his arraingement stand mute. ${ }^{15}$

The rule not only demanded proof of the principal's guilt, but also the formal requirement of 'attainder'. ${ }^{16}$ The accessory was given the option of waiving his right not to be tried before conviction of his principal. If he chose this and was convicted, judgment against him had to be postponed until the later conviction (if any) of the principal. ${ }^{17}$ To overcome 'the administrative quagmire caused by this rule, ${ }^{18}$ the English courts in the 16 th century resorted to a legal fiction '[t]hat all persons present aiding

11 KJM Smith, A Modern Treatise on the Law of Criminal Complicity (Clarendon Press, 1991) 22.

12 Thomas Hobbes, Leviathan (Penguin, first published 1651, 1991 ed) Pt 2, ch 27.

13 Smith, above n 11, 24.

14 In the 13th century, Henri de Bracton was already clear that the principal offender had to be convicted before any question of accessorial liability could arise. Bracton, Bracton on the Laws and Customs of England (SE Thorne trans, Belknap Press, first published 1250, 1968 ed) F 128, 360-361.

15 Sir Edward Coke, The Second Part of the Institutes of the Laws of England (Garland, first published 1797, 1979 ed) 183.

16 JR Lander, 'Attainders and Forfeiture 1453-1509' (1961) 4 The Historical Journal 119.

17 Sir Matthew Hale, History of the Pleas of the Crown (first published 1736, 1971 ed) 623 and Coke, above n 15, 183.

18 Smith, above n 11, 23. 
and abetting are principals' ${ }^{19}$ This fiction was not extended to accessories before the fact. The strict rule requiring proof of attainder for accessories before the fact persisted until abolished by statute in $1848 .^{20}$

As a consequence of this procedural history, the common law evolved distinctions between the nature of the offence that was assisted or encouraged, ${ }^{21}$ and the degree of participation. The perpetrator of the offence was designated the 'principal in the first degree', whereas parties who assisted or encouraged during the perpetrator's crime were described as 'principals in the second degree'. Parties who were not physically present during the commission of the offence were divided into 'accessories before the fact' (assisting or encouraging before the commission of the perpetrator's offence) or 'accessories after the fact' (assisting after the commission of the perpetrator's offence). ${ }^{22}$ The Crown could proceed against the principal in the second degree at any time, but accessories before the fact could not be prosecuted unless and until the principal who committed the crime was duly convicted. ${ }^{23}$ The only substantive difference between a principal in the second degree and an accessory before the fact was (and is) that the principal was present during the commission of the felony and the accessory before the fact was not. Presence was used as crude criterion for distinguishing between levels of culpability, with the assumption that an accessory who had been present was more culpable than if not. Presence was very liberally interpreted and proved to be a

19 Foster, above n 6, 348. Applied in $R v$ Griffiths (1553) 1 Plowden 97; 75 ER 152.

20 Criminal Law Act 1848 (UK). The Accessories and Abettors Act 1861 (UK) affirmed the common law principle of equal eligibility for punishment of all parties, that is, a person who aided, abetted, counselled or procured an offence was liable to be tried, indicted and punished as a principal offender. Similar statutory provisions have been enacted in all Australian jurisdictions: Criminal Code (Cth) s 11.2; Criminal Code (ACT) s 45; Crimes Act 1900 (NSW) s 346; Criminal Code (NT) s 12; Criminal Code (Qld) s 7; Criminal Law Consolidation Act 1935 (SA) s 267; Criminal Code (Tas) s 3; Crimes Act 1958 (Vic) s 323; Criminal Code (WA) s 7.

21 In offences of treason, all accessories, irrespective of their participation, were deemed by law to be principals.

22 Although the distinctions and terminology between principals in the second degree and accessories before the fact are largely of historical interest, these distinctions and terminology continue to infect the language of lawyers and judges.

23 In 1250, Bracton noted no distinction between accessories before or at the crime. No justification or explanation was provided as to why accessories before the fact were not to be designated principals. Originally no distinction was registered between those secondary participants who were present or absent at the commission of the offence. There is some controversy about when the distinction evolved between an accessory before and at the fact. Coke maintains in his commentary on the Statute of Westminster (1275 33 Ed I) that an accessory may incite, procure or provide the means ('furnishing of a weapon of force to do the act') indeed practically anything so long as such a person is 'not present when the act is done; for if the party commanding, furnishing with weapon or aiding, be present when the act is done then he is principal: Coke, The First Part of the Institutes of the Laws of England (Clarke and Sons, first published 1628, 1832 ed) 182. Foster suggests that such a view was in advance of the law at the time: Foster, above n 6,348 . 
highly elastic concept from the moment of its introduction as a point of differentiation:

When the law requireth presence of the accomplice at the perpetration of the fact, in order to render him a principal, it doth not require a strict, actual, immediate presence, such a presence as would make him an eye or ear witness of what passeth. ${ }^{24}$

Archer would have been an accessory before the fact, liable only to conviction after Saunders had been convicted and suffered by way of attainder.

Whilst the change in status of 'accessories at the fact' to 'principals in the second degree' was introduced to ensure eligibility at trial to ensure the reach of the law, the benefit of clergy (in and of itself a source of vexed complexity $)^{25}$ continued to operate in the opposite direction to mitigate the law's severity. ${ }^{26} \mathrm{Up}$ to the end of the 15 th century benefit of clergy was similarly available to all participants in a felony. But thereafter, this notorious mitigatory device was cut back by a series of statutes, and with the creation of new felonies the courts began a long process of nitpicking statutory interpretation. For example, Hawkins stated: 'a statute excluding the principals from benefit of clergy doth not thereby exclude the accessories before or after. Neither doth a statute excluding the accessories thereby exclude the principals'. ${ }^{27}$ The courts appeared not to be concerned with the nature of the participation, but rather with mitigating the harshness of the law. ${ }^{28}$ This highlights the incomplete and inconsistent nature of the identic turn. Sometimes accomplices were treated the same as principal offenders, at others not.

The complex procedural history had substantive effects that were unrelated to the blameworthiness of an accessory, but were instead motivated by a concern to bypass and/or draw upon procedural impediments. Judges were motivated by conflicting concerns of ensuring a culpable accused did not escape the law on the one hand, whilst extending the benefit of clergy to mitigate the harshness of law on the other. These inconsistencies and confusions reflected and reinforced the apparent absence of concern

24 Foster, above n 6, 349-350.

25 J Baker, An Introduction to English Legal History (Butterworths, 2002) 521-524.

26 Foster, above n 6, 355: '[C]ases without number may be cited to show in general how extremely tender the Judges have been in the construction of statutes which take away clergy, sometimes even to a degree of scrupulosity excusable only in favour of life'.

27 William Hawkins, Pleas of the Crown, 1716-1721 (Professional Books, first published 1716-1721, 1980 ed) 476.

28 Sir James Fitzjames Stephen, A History of the Criminal Law of England Volume I (MacMillan and Co, 1883) 466:

If a statute taking away clergy did not expressly mention all the possible cases and take away clergy in all of them both from principal and from his accessories both before and after, clergy remained in every omitted case. Hence questions arose on the special wording of every statute as to whether it ousted an offender of clergy not only if he was convicted but if he pleaded guilty, if he stood mute, etc., and similarly his accessories. Hardly any branch of the law was so technical and so full of petty quibbles as this. 
about, or articulation of, fault. The effect of the procedural identic turn was that some parties were treated the same, whilst others were treated differently, and there was no clear explanation why.

\section{A Elements of Accessorial Liability}

The lack of clarity of how the culpability of accessories was (and is) constructed was (and is) reflected and reinforced in the diffuse nature of the elements of liability. Since the time of Bracton, the law has provided a set of terms to describe and inscribe the liability of accessories before and at the fact. From early times also there has been a looseness and slipperiness of language reflecting and reinforcing the shifting foundations of accessorial liability. This looseness is apparent in Saunders and Archer, with Plowden moving between various terms to describe the nature of Archer's involvement: 'persuades', 'command', 'assistance and advice', 'directed', 'aid and advice', 'procure', 'assent', and 'procured and advised'. Plowden concludes:

But I greatly approve of the said opinions of the justices concerning the accessory in the case before reported, because the poisoning of the daughter was a distinct fact, to which Archer gave no advice nor counsel, and whose death he did not procure. ${ }^{29}$

At the time that Saunders and Archer was decided, there were no particular elements of the actus reus associated specifically with either a principal in the second degree or an accessory before the fact. ${ }^{30}$

A series of similar words were relied upon by the legislature, judiciary and treatise writers but none captured the essence of accessorial liability. The inconsistency of language occurs in statute and at common law, as Foster noted:

Some statutes make use of the word accessories simply without any other words as descriptive of the offence. Others have the words, abetment, procurement, helping, maintaining, and counselling. One describeth the offence by the words, command, counsel or hire; another calleth the offenders, procurers or accessories. One having made use of the words, comfort,

$29 \quad R v$ Saunders and Archer (1573) 2 Plowden 473; 75 ER 706, 711.

$30 \quad$ Foster above $\mathrm{n} 6,131$ : ' $[\mathrm{I}] \mathrm{t}$ is a principle in law which can never be controverted that he would procureth a felony to be done is a felon. If present he is a principal if absent an accessory before the fact'. See also Hale, above n 17, 615-666, 438: 'An accessory before is he that being absent at the time of the felony committed doth yet procure, counsel or abet another to commit a felony ... for if he be present he is a principal'. Although it is now customary to reserve 'aiding and abetting' for secondary parties present at the offence and 'counselling and procuring' for those absent, there is no substantive rule delimiting modes of complicity on the basis of presence. Despite the lack of any strict need to specify in a charge whether a party participated as a principal or by aiding, abetting, counselling or procuring, the House of Lords in Maxwell's case strongly and appropriately emphasised the desirability of indictments indicating the true factual nature of the case to be presented against any defendant: [1978] 1 WLR 1350, 1352, 1357, 1360. The lack of distinction between accessories before the fact and principals in the second degree is unsurprising given their common ancestry. 
aid, abet, assist, counsel, hire and command, immediately afterwards in describing the same offence in another case useth the words counsel, hire or command only. One statute calleth them consellors and contrivers of felonies; and many others make use of the terms counsellors, aiders and abettors, or barely aiders and abetters. ${ }^{31}$

Foster asserts that prosecutors need not be limited to the literal meanings explicitly used in statute, but rather draw upon 'the true legal import of the words' developed at common law. ${ }^{32}$ Foster supports his argument by reference to another case on accessorial liability in which an indictment "was held to be sufficient even though the words of the statute ... were not pursued': ${ }^{33}$

I take this case to be good law, though I confess it is the only precedent I have met with, where the words of the statute have been totally dropped. And I rather incline to this opinion, because I observe the Legislature in Statutes made from time to time concerning accessories before the fact, hath not confined itself to any certain Mode of Expression; but hath rather chosen to make use of a variety of words, all terminating in the same general idea. ${ }^{34}$

Contemporary common law retains the list approach to accessorial liability - the prosecution need prove that the accomplice either aided, abetted, counselled or procured, with only 'procure' having any technical meaning. ${ }^{35}$ The elements of accessorial liability were (and are) loosely enunciated and applied.

The reliance on a list of words with similar meanings was also apparent amongst the treatise writers. For example, Coke analysed specific terms defining accessorial liability in the Statute of Westminster I thus:

1. [Commandment] Praeceptum. Under this is understood all those that incite, procure, set on or stir up any other to do the fact, and are not present when the fact is done.

3. [Aid] Auxilium. Under this word is comprehended all persons counselling, abetting, plotting, assenting, consenting, and encouraging to do the act, and are not present when the act is done; for if the party is commanding, furnishing with weapon or aiding to be present when the act is done, then is he principal. ${ }^{36}$

These definitions are broad, providing a long list of actions for what might otherwise be translated simply, for example, auxilium as aid. The list of verbs suggests a desire by Coke to ensure a culpable accused can be brought to justice, and not escape by some minor technicality. However, the list also reflects the complexity of the reach of the doctrine of complicity. The doctrine needed (and needs) to distinguish between

31 Foster, above n 6, 130-131.

32 Ibid, 126-127.

33 Ibid, 130.

34 Ibid.

35 Andrew Ashworth and Jeremy Horder, Principles of Criminal Law (Oxford University Press, 7th ed, 2013) ch 10.

36 Sir Edward Coke, The Second Part of the Institutes of the Laws of England (Garland, first published 1797, 1979 ed) 182-183. 
minor assistance and villains who are worse than the actual perpetrator. It also needed (and needs) to cross all felonies, ranging from minor property offences to homicides. Accordingly, there has been consistent authority that the terms of liability were not to be interpreted literally, but represented instead legal concepts. Accessorial liability was (and is) thus limited by the conceptual rather than the terminological. It is articulated and regarded as a broad idea rather than specific language of liability. What then was (or were) the concept/s of accessorial liability?

\section{B Incomplete Justifications for Accessorial Liability}

There is an intuitive appeal to extending liability to accessories. Sir Matthew Hale's chapter on principal and accessory liability in the History of the Pleas of the Crown (1763) begins with no justification of accessory liability, since none was perceived as necessary. The culpability of accessories is well-represented in the popular imagination in literature, with characters such as Iago, Lady Macbeth and Fagin. However, this self-evidence does not extend to the theoretical basis nor to the boundaries of such involvement. It is arguable that the lack of clarity is due to policy dilemmas about the reach of criminal law - a balance between not allowing the guilty to escape but also protecting against the overreach of the law. ${ }^{37}$ How much or how little must a person do in relation to a principal offence to incur accessorial liability?

More significantly, judicial confusion and conflict is because the doctrine of complicity disrupts two paradigms of criminal responsibility. Legal doctrine assumes and asserts agency and autonomous action. ${ }^{38}$ That is, a free acting and fully informed agent, choosing either to behave in a proscribed way or to bring about an unlawful state of affairs. ${ }^{39}$ In addition, models of criminal liability revolve around direct involvement. However, accessories, particularly accessories before the fact like Archer, are only indirectly involved in the commission of the crime. Cases such as Archer challenge the acceptability and operation of chance and risk, due to Archer's limited capacity to exercise control over the incurring of responsibility. Attributing blameworthiness to accessories also has the potential to undermine the agency and autonomy of the principal was Saunders merely Archer's minion, and thus lacking in free agency? Although the criminal law accepts that accessories are indirectly involved in the commission of crime, the theoretical justifications for liability are less well articulated..$^{40}$

37 This tension was also revealed in the application of the Bloody Code and the development of the benefit of clergy.

38 See for example, Ashworth and Horder, above n 35, ch 4.1. They assert that autonomy is a central principle of criminal law, that each individual should be treated as responsible for his or her own behaviour.

39 HLA Hart, Punishment and Responsibility (Clarendon Press, 1968) ch 1.

40 One way of grounding liability for complicity has recently been developed in the United Kingdom in Pt 2 of the Serious Crimes Act 2007 (UK). This approach 
The dominant model at the time of Archer and in contemporary Australian common law is derivative liability. ${ }^{41}$ That is, the liability of an accessory was (and is) contingent upon the actual occurrence of the principal offence: 'there can be no accessory without an offence to the Crown'. ${ }^{42}$ This 'parasitic'43 liability challenges standard legal modes of participation. Despite the procedural and penal identic turns of treating accessories the same as principals, this did (and does) not overcome the difference in the nature of liability - a principal in the first degree's liability is direct, whilst an accessory's is derivative.

The accessory is indeed a felon, but guilty of a felony of a different kind from that of the principal. It is, if I may use the expression, a derivative felony connected with and arising out of that of the principal and cannot exist without it. ${ }^{44}$

To make a person an accessory is to put them in a particular relation to the act of another, but the law has not clearly articulated the connection between the accessory and principal. The idea of shadow or parasitic liability assumes that derivative liability is something less than the principal's liability, just as a shadow or parasite is dependent on something more substantial. However, this hierarchy of guilt can be disrupted when it is the accessory who is the true villain, for example, in organised crime cases where the crime boss orders an act but does not commit it. ${ }^{45}$

Derivative liability was (and is) a form of shadow liability - but even here there are significant differences between the principal's and the accessory's actions and mens rea. As I demonstrate below through an analysis of Archer's case, the shadow principles of liability were (and are) not easily applied to the actus reus - as it is the principal who does the act and causes the prohibited consequences, not the accessory. It appears easier to apply shadow principles of liability to mens rea, to assert some kind of amalgam of purpose, but even here there are problems. Must an accessory possess identical, or at least broadly equivalent, mens rea as the perpetrator?

regards complicity as an inchoate offence, in the same category as offences of attempt and conspiracy. If a person has a mental association or commitment to a criminal objective, manifested in and evidenced by overt action, then he or she can be liable to the inchoate offences of incitement and assistance, regardless of whether or not another person proceeds with the offence. Here, culpability is attributed on the basis that involvement has increased the likelihood the principal offence will occur, and participation is a sufficiently strong manifestation of the accessory's criminal proclivities to warrant punishment.

41 Giorgianniv The Queen (1985) 156 CLR 473.

$42 R v$ Saunders and Archer (1573) 2 Plowden 473; 75 ER 706, 711.

43 Smith, above n 11, 3.

44 Foster, above n 6, 343.

45 The need to remain open to the possibility of the accessory being more culpable than the principal is yet another reason for the openness of the contemporary doctrine of complicity. 


\section{Moral Basis For Responsibility}

In his in-depth analysis of the doctrine of complicity, Smith asserts that derivative or parasitic structure does not comfortably lend itself to punishing deserving but unorthodox modes of participation and sets up doctrinal 'stresses' or 'fractures'. ${ }^{46}$ I would extend this argument to the doctrine of complicity generally. The doctrine of complicity does not satisfy criminal legal doctrinal assumptions about agency and autonomy. Despite the fragility of these assumptions when applied to accessories, no persuasive alternatives have been articulated. This is another example of the identic turn. Derivative liability was (and is) modelled upon the same principles as principal liability, but the differences keep intruding. I will demonstrate the problems of accessorial liability and traditional models of blameworthiness through an analysis of classic models of culpability operating at the time of Saunders and Archer and articulated clearly in structures of contemporary law: intention, act and consequence. ${ }^{47}$ Traditional models of liability were (and are) assumed but warped in their application to accessories.

\section{A Subjective Culpability-Transferred Malice}

Plowden's report of Saunders and Archer appears to rest firmly on the pattern of subjective culpability, ${ }^{48}$ that is, the focus in attributing culpability is upon the state of mind of the accused. The legal theorist George Fletcher describes the pattern of subjective culpability as taking 'the actor's intent to violate a protected interest as the core of criminal conduct'. ${ }^{49}$ Saunders' case continues to be regarded and cited as an early authority (and even progenitor) of the doctrine of transferred malice. ${ }^{50}$ The concept of transferred malice and the emphasis upon intention in attributions of culpability was articulated in relation to Saunders:

If A. intending to kill his wife gives her a poisoned apple, and she being ignorant of it gives it to a child against whom A. never meant any harm, and against his will and persuasion, and the child eats it and dies, this is murder by A. and a poisoning by him, but the wife, because ignorant, is not guilty. ${ }^{51}$

46 Smith, above n 11. Even the long established complementary notion of innocent agency, which absorbs many problematic examples of secondary participation by transmuting 'accessories' into principals, cannot always convincingly accommodate complicity's leftovers.

47 George Fletcher, Rethinking Criminal Law (Little Brown, 1978).

48 However, Crofts has argued that the case is much more complex than solely drawing upon the pattern of subjective criminality: Crofts, above $\mathrm{n} 2$.

49 Fletcher, above n 47, 388.

50 See for example, Simon Bronitt and Bernadette McSherry, Principles of Criminal Law (Law Book Company, 2005) 174. Saunders' case is cited as an authority for the principle: 'Where a person intends to commit the requisite physical element, he or she may still be convicted even where the victim is not the intended victim'. $R v$ Saunders and Archer (1573) 2 Plowden 473; 75 ER 706, 706-707. 
This expressed the principle that a person could be found guilty of murder if, having the requisite mens rea with respect to the killing of $\mathrm{X}$, by some mischance $\mathrm{Y}$ should be killed instead of $\mathrm{X}$. Coke also represented the case in similar subjectivist terms:

The malice intended to one, egrediturpersonam, and makes the death of another upon that malice, Murder, and qualifies the act in the same manner, as if it had had its due effect ... A lays poison to kill $\mathrm{B}$ and $\mathrm{C}$ at misadventure takes it and dies, Murder in A. Contrary if it had been laid to kill Rats; then infortunium. ${ }^{52}$

This expression of intentional wrongdoing as particularly wicked was demonstrated in Plowden's report of Saunders and Archer:

John Saunders had a wife whom he intended to kill ... and he opened his design to ... Alexander Archer, and desired his assistance and advice in the execution of it, who advised him to put an end to her life by poison. With this intent the said Archer bought the poison, viz. arsenick and roseacre, and delivered it to the said John Saunders to give it to his wife, who accordingly gave it to her, being sick, in a roasted apple, and she eat a small part of it, and gave the rest to the ... infant. ${ }^{53}$

Even within this paragraph, the emphasis is upon Saunders' intention, a word used repeatedly throughout the case, even stating the 'intent was evil'. ${ }^{54}$ The selection and use of the word 'design' is also consistent with a particular notion of malice involving planning and intention. On this account, Saunders' intentional poisoning was regarded as particularly wicked as his actions were done in cold-blood rather than spontaneously and in 'hot-blood'.

This emphasis upon intention in attributions of blameworthiness also appears applicable to Archer. Plowden, too, emphasises Archer's intent: 'With this intent the said Archer bought the poison, viz. arsenick and

52 In his quest to assert a unity of general principles of law across history, Coke referred not only to Saunders' case but also to Bracton as an authority for the doctrine of transferred malice:

Malice prepensed is, when one compasseth to kill, wound or beat another, and doth it sedatoanimo. This is said in law to be malice forethought, prepensed, malitiapraecogitata. This malice is so odious in law, as though it be intended against one, it shall be extended towards another.* Si quisunumpercusserit, cum aliumpercuterevellet, in felonious tenctur: * Bracton, lib 3 Fol 1552 Bracton 275 .

Upon rereading Bracton, I have been unable to ascertain Coke's source. These reinterpretations are plausible due to a slippage in emphasis from earlier homicide law's emphasis upon the act of ambush and lying in wait to reading this as requiring premeditation. See J Kaye, 'The Early History of Murder and Manslaughter: Part I' (1967) 83 Law Quarterly Review 365-395. Coke reinterpreted earlier authorities to support his organisation of wickedness. Coke was strongly criticised by Stephen for relying upon earlier authorities to support his assertions. For example, Stephen criticised Coke's unlawful act murder rule as unsupported by the cases cited: Sir James Fitzjames Stephen, A History of the Criminal Law of England Volume III (Macmillan and Co, 1883) 57-58.

$53 \quad R v$ Saunders and Archer (1573) 2 Plowden 473; 75 ER 706, 707.

54 Ibid. 
roseacre, and delivered it to the said John Saunders to give it to his wife'. ${ }^{55}$ Here, the parasitic nature of complicit liability is highlighted. Archer had the intention to aid and facilitate the offence, but had no intention to commit the offence. Archer had a form of shadow intent, an amalgam of purpose with Saunders.

Nevertheless, Archer could be regarded as particularly wicked because he came up with the idea of how to kill Saunders' wife, and also procured the poison. Poisoning was characterised and understood as particularly wicked because it was 'an act of deliberation odious in law' ${ }^{56}$ It demonstrated the firmness of the actor's resolve to kill and reason untainted by passion:

For, in the point of solid and substantial justice, it cannot be said that the mode of killing, whether by stabbing, strangling or shooting, can either extenuate or enhance the guilt: unless where, as in the case of poisoning, it carries with it an internal evidence of cool and deliberate malice. ${ }^{57}$

Poisoning was classified as express malice because, like stabbing, it showed 'a direct and deliberate Intent to kill another'. ${ }^{58}$ Treatise writers thus utilised poisoning as an exemplar of malice because it was an act of deliberate wrongdoing, based on thought untainted by passion. Plowden also comments:

But when he lays the poison with an intent to kill some reasonable creature, and another reasonable creature, whom he does not intend to kill, is poisoned by it, such death shall not be dispunishable, but he who prepared the poison shall be punished for it, because his intent was evil. And therefore it is every man's business to foresee what wrong or mischief may happen from that which he does with an ill intention, and it shall be no excuse for him to say that he intended to kill another, and not the person killed. ${ }^{59}$

In Saunders and Archer, this reasoning is only applied to Saunders, and not to Archer. Plowden justifies this by asserting that this was because Archer did not 'do the act'. ${ }^{60}$ There is a lack of coherence and credibility in the reasoning of Plowden here. Plowden asserts Archer 'did not precisely procure her death, nor advise him to kill her'; Archer 'did not assent that the daughter should be poisoned, but only that the wife should be poisoned, which assent cannot be drawn further than he gave it, for the poisoning of the daughter is a distinct thing from that to which he was privy, and therefore he shall not be adjudged accessory to it'. ${ }^{61}$ The difficulty is that Archer clearly had the intention to support Saunders with his intention to kill, but this was support was only for the death of the

55 Ibid.

56 Hale, above n 17, 455.

57 William Blackstone, Commentaries on the Laws of England. Book the Fourth (Dawsons of Pall Mall, 1769) 193.

58 Hawkins, above n 27, 80-81.

$59 \quad R v$ Saunders and Archer (1573) 2 Plowden 473; 75 ER 706, 708.

60 Ibid.

61 Ibid, 707. 
wife, not the child. However, the reasoning is not persuasive. Why doesn't the principle of transferred malice apply to Archer?

One argument is that the liability of Saunders was itself complex, with judges relying in part upon the fledgling concept of transferred malice. The judges could have been reluctant to extend the principle of transferred malice to Archer, yet another point removed. ${ }^{62}$ This returns us to the underlying concern about the reach of the criminal legal system. If an accessory has indicated a willingness to support criminal activity, how far will this support extend? Is there a kind of 'blank cheque' responsibility? ${ }^{63}$ This was (and is) regarded as a problem of variation. How much variation from the original plan by the principal is too much?

\section{B Harmful Consequences}

The issue of variation/deviation is linked to the second classic model of blameworthiness, harmful consequences. This pattern was developed particularly in homicide, where culpability was ascribed due to the harmful consequence of death. ${ }^{64}$ Treatise writers retained and expressed the medieval notion that unnatural slayings were wicked because they caused death: 'For all homicide is presumed to be malicious, until the contrary appeareth upon evidence'. ${ }^{65}$ Malice was assumed because of a slayer's association with the evil of death. ${ }^{66}$ Treatise writers sustained the medieval notion that unnatural slayings were a transcendental and social harm to justify an assumption of malice.

\section{Religious Harm}

Treatise writers expressed homicide as a transcendental harm, and drew upon religious notions to justify culpability and punishment. The law retained medieval constructions of homicide as a transcendental harm, an offence against God. Killing was regarded as inherently wicked because it breached the sixth commandment and took away life, "which is the

62 This reluctance to extend the doctrine of transferred malice has also been demonstrated in contemporary law. The House of Lords considered the doctrine of transferred malice in Re Attorney-General's Reference (No 3 of 1994) [1988] AC 245. The House of Lords refused to extend the doctrine of transferred malice for the charge of murder of a child who had been born alive and then died, but had been a foetus at the time that an accused had stabbed the mother. It was held that this was too far removed from the accused's initial intent.

63 Smith, above $\mathrm{n} 11,13$. For example, if $\mathrm{X}$ gives $\mathrm{D}$ a gun for the purposes of the murder of one victim, is $\mathrm{X}$ then liable if $\mathrm{D}$ goes on a killing spree?

64 This pattern of liability is apparent in cases of involuntary manslaughter, where an accused lacks the mens rea for murder, but has caused the death of the victim.

65 Blackstone, above n 57, 201.

66 This is consistent with arguments that up until the early 19th century, the criminal trial operated on something closer to a presumption of guilt than of innocence. See John Langbein, 'The Criminal Trial Before Lawyers' (1978) 45 University of Chicago Law Review 263, 263. 
immediate gift of the great creator' ${ }^{67}$ Religious sources not only contributed to the organisation of wickedness, they also justified and required punishment:

We are next to consider the crime of deliberate and wilful murder; a crime at which human nature starts, and which is I believe punished almost universally throughout the world with death. The words of mosaical law (over and above the general precept to Noah, that 'whoso sheddeth man's blood, man shall his blood be shed') are very emphatical in prohibiting the pardon of murderers. ${ }^{68}$

As a desecration of the natural order, killing required expiation, and a failure to do so could result in harm to the community because it could distance the community from God.

Religious conceptions of the wickedness of unnatural slayings and the requirement of expiation threw a halo of moral sanctity over homicide law and claims of jurisdiction. The sovereign was organised as God's representative, with a right and obligation to restore order where violations or breaches of the divine and natural order occurred. Thus, in the Saunders' case, Plowden states at the beginning of the case report, '... the reign of the Lady Elizabeth, by the grace of God, of England, France, and Ireland Queen, defender of the faith, \&c'. ${ }^{69}$ The formulaic expression of the Queen as ruling as a consequence of God, and defending the faith, justified the organisation of criminal law. The laws of crime sustained medieval notions of homicide as tainted and tainting, and consequently requiring expiation, expressed not only through capital punishment but the institutions of forfeiture. Deodands required the forfeiture to the Crown of all instruments that caused death until $1846 .^{70}$ All who caused unnatural death, including suicides, were required to forfeit all worldly goods, including those later excused or pardoned on the grounds of accident or self-defence. Homicide law thus rested on the foundation of death conceived as an evil, resulting in the tainting of those involved. Malice was assumed as the slayer was tainted by the fact of death. The consistency of the common law with the laws of God contributed to resolving the question of jurisdiction, even whilst treatise writers claimed malice as a legal question.

\section{$2 \quad$ Harm to the Social}

The pattern of liability extended beyond transcendental harm to include a collective assertion of harmful consequences. Saunders' case proceeds on the assumption that someone must be punished, because the 'Queen has lost a subject': ${ }^{71}$

$67 \quad$ Blackstone, above n 57, 177.

68 Ibid, ch 14, 194.

$69 R v$ Saunders and Archer (1573) 2 Plowden 473; 75 ER 706, 706.

70 Jacob Finkelstein, 'The Goring Ox: Some Historical Perspectives on Deodands, Forfeitures, Wrongful Death and the Western Notion of Sovereignty' (1973) 46 Temple Law Quarterly 169; Fletcher, above n 47, 343-344. $R v$ Saunders and Archer (1573) 2 Plowden 473; 75 ER 706, 708. 
[Y] et it shall be murder in him, for he was the original cause of the death, and if such death should not be punished in him, it would go unpunished ...

The case expressed a cause and effect argument, that the Queen has suffered harm because she has lost a subject, thus someone must be punished. Here, the Queen is conceptualised not only as a representative of God on earth, but as a representative of the interests of the community. ${ }^{72}$ This was expressed in the long-term notion of crime as a breach of the sovereign's peace, and stated in Saunders' case as 'against the peace of the Queen'. ${ }^{73}$ This was a formulaic expression of the Queen's interest in the order of society, and as a representative of the community.

Blackstone expressed this idea through social contract theory. Judgment and punishment by the sovereign is authorised because crime is a breach of the social contract:

The law by which they suffer was made by their own consent; it is part of the original contract into which they entered, when first they engaged in society; it was calculated for, and has contributed to, their own security. ${ }^{74}$

Crime was thus a breach of contract, a violation of the agreed upon order, and therefore culpable. The interests of the community are represented by the sovereign "who bears the sword of justice by the consent of the whole community'. ${ }^{75}$

Homicide was conceptualised as harming not only (or even particularly) an individual, but society as a whole:

Murder is an injury to the life of an individual; but the law of society considers principally the loss which the state sustains by being deprived of a member, and the pernicious example thereby set, for others to do the like. ${ }^{76}$

Crime was organised as an infringement of public rights, with the public interest represented by the sovereign (hence the "pleas of the crown'). Accordingly crimes, particularly homicides, were conceptualised as a social wrong and harm. This communicated a social account of wickedness - with crime a breach of the law established for the 'government and tranquillity of the whole'. ${ }^{77}$

Treatise writers communicated a notion of unnatural slayings as wicked because of the evil of death. During this time, the harm of death was conceptualised on the social and transcendental levels, rather than as an injury done to an individual or their surviving family. ${ }^{78}$ The pattern of harmful consequence contributed to the authority of the criminal law, relying upon religious patterns and social contract theory to articulate a right and responsibility to judge and punish. The sovereign was conceptualised as both God's representative on earth and as representative of

72 Hurnard, above n 7; Finkelstein, above n 70.

$73 \quad R v$ Saunders and Archer (1573) 2 Plowden 473; 75 ER 706, 707.

74 Blackstone, above n 57, 6.

75 Ibid, 8.

76 Ibid, 6.

77 Ibid, 7.

78 Hurnard, above n 7. 
the public interest. Homicide was wicked because it caused harm to the sovereign.

The above reasoning was applied to Archer, but incompletely. Archer had procured the poison and encouraged and assisted his friend to commit homicide. Under the pattern of harmful consequences the identity of the victim is irrelevant, for Archer was implicated in the harmful consequence - the Queen had lost a subject. ${ }^{79}$ The fact of death should have been enough. However, this was only incompletely applied as Plowden argues that the poisoning of daughter was a distinct fact. This highlights a disjunction between the primary and derivative liability and foundational patterns of blameworthiness. Under existing principles at the time Archer should either have been subject to the same punishment as Saunders (death), or he should have been acquitted. Instead, the judges chose a middle way to express his involvement in the loss of human life. The judges clearly accepted that Archer had some involvement in the homicide, despite the variation of the identity of the victim. In consequence, Archer was tainted by his involvement. Although Archer was not sentenced to death, he was required to purchase a pardon. ${ }^{80}$ This reflects the idea that Archer was tainted, albeit indirectly, and he had to undertake a ritual to undo this taint. $^{81}$

\section{Manifest Criminality}

A third traditional way of conceptualising blameworthiness is through a focus on the act. Fletcher labelled this pattern of blameworthiness 'manifest criminality' and argued that 'manifest criminality' was the dominant 'pattern of criminality' until the late 18 th century. ${ }^{82}$ Manifest criminality is based on the notion that an act that threatens the peace and order of community life should be penalised. A central aspect of the concept of this pattern of blameworthiness is that criminality is manifest, that is, it can be seen. Binder has persuasively argued that homicide law during this time focused upon the act of killing, rather than the fact of death. In order to be regarded as an unnatural slaying, homicide law required a killing that had to be 'an act culturally recognised as a violent assault'. ${ }^{83}$ Binder frames this in part as a question of evidence. Given the tendency of

$79 \quad$ Ashworth and Horder, above n 35, 443. They note that the case-law on the culpability of accomplices for 'unexpected results' is inconsistent. Their reasoning is consistent with a harm narrative, whereby an accomplice who has agreed to assist in a murder should still be responsible if an unexpected victim is slain.

80 Hurnard, above $\mathrm{n}$ 7. This principle also applied to an accused who had killed in self-defence. Although acquitted, an accused had to purchase a pardon, because of their involvement in a homicide.

81 See Trisha Olson, 'Of Enchantment: The Passing of the Ordeals and the Rise of the Jury Trial' (2000) 50 Syracuse Law Review 109, ch 2; Crofts, above n 2.

82 Fletcher, above n 47, 61.

83 Guyora Binder, 'The Meaning of Killing' in Markus Dubber and Lindsay Farmer (eds), Modern Histories of Crime and Punishment (Stanford University Press, 2007) 88, 93. 
men to be armed, the reliance upon violence to resolve disputes, and poor medical treatment, death was common. The slaying had to be manifestly criminal, to offend against the collectively agreed upon social order, in order to attract the attention of royal officials by desecrating the king's peace. ${ }^{84}$ The quintessential act envisaged by homicide law was the mortal wound inflicted in a violent act - such as stabbings or violent assaults in a cruel, stealthy or dishonourable manner. Treatise writers devoted pages to methods of killing, highlighting the requirement of a threat or offence against the order of community life. ${ }^{85}$

The focus upon the act of killing was demonstrated in the report and representations of Saunders and Archer. In the sentence summarising the facts of the case, Plowden uses the word poison five times, and twice in that sentence states that the poison used was 'arsenick and roseacre'. ${ }^{86}$ When representing the case, treatise writers also focused on the act of killing. They specifically stated that the accused had killed with poison, rather than simply enunciating principles from the case in general terms.

The consistent reference to poison by legal scholars drew upon community understandings and fears of wickedness. Poisoning was regarded as particularly abhorrent, not because it involved an act of deliberation, but because of biblical and social repugnance of killings by stealth and dishonour. Dishonourable killings, acts of deliberate cruelty, particularly where there had been some disparity of strength or vantage ground between the killer and the victim, were still regarded as undeserving of any mitigation, whether premeditated or not. ${ }^{87}$ Treatise writers drew upon and reflected this notion of dishonourable slayings as particularly abhorrent from legal history, and social and religious understandings.

In addition, poisoning was constructed as particularly criminal and wicked because it could happen to anyone, and could not be protected against. All were at risk. Coke in particular dwelled on this aspect:

Poyson, (Venuenum, a venis, quia a venispermeat) is, as hath been said, the most detestable of all, because it is most horrible, and fearfull to the nature of man, and of all others can be least prevented, either by manhood, or providence ... ${ }^{88}$

Coke framed his claims of wickedness in common sense terms, and he supported his assertions through reference to earlier legal authorities such as Fleta and Bracton, and notes that for some time, poisoning was regarded as high treason, with punishment of a lingering and grievous death; 'the offender would be boyled to death in hot water'. ${ }^{89}$

\footnotetext{
84 Ibid, 107.

85 For example, under a category of 'Killing' Coke enunciated the various methods by which a person could be slain: Coke, above n 15, cap 7, 48 .

$86 \quad R v$ Saunders and Archer (1573) 2 Plowden 473; 75 ER 706, 707.

87 Binder, above n 83; Jeremy Horder, Provocation and Responsibility (Clarendon, 1992).

88 Coke, above n 15, ch 14, 196.

89 Ibid, cap 7, 48.
} 
In asserting that poisoning always expressed malice, treatise writers enunciated an abhorrence of the act. They expressed and excited emotional reactions of fear and disgust. This rhetorical expression and appeal to emotion occurred not only in Plowden's report of Saunders' case, but was particularly emphasised by Coke through a focus on the mechanics of poisoning:

Also the poysoning of any man, whereof he dieth within the year, implieth malice, and is adjudged wilfull murder of malice prepensed. One may be poysoned four manner of waies: Gustu, by taste, that is by eating or drinking, being infused into his meat or drink; Anhelitu, by taking in of breath, as by a poysonous perfume in a chamber or other room; Contactu, by touching; and lastly Supportu, as by a cypher or the like. Now for the better finding out of this horrible offence, there be divers kind of poysons, as the powder of Diamonds, the power of Spiders, lapis caresticus (the chief ingredient whereof is Soap), Cantbarides, Mercury sublimate, Arsenics, Roseacre, etc. ${ }^{90}$

The dwelling upon the mechanics of poisoning reiterated and illuminated Coke's fear and abhorrence of this method of killing. The lack of citations for any cases where these methods were used suggests that Coke is drawing upon his fears to enunciate the myriad of ways in which one may be poisoned (although the reference to arsenics and roseacre in the last sentence suggests he may have been thinking of Saunders' case).

Poisoning thus had particular resonance as a method of killing. It excited fear and horror, and it was fundamentally unnerving. It could happen to any of us at any time, and cannot be protected against. Treatise writers emphasised Saunders' use of poison to draw upon notions of manifest criminality and assert legal interest and capacity in the identification of wickedness and appropriate punishment. However, what is missing from treatise writers' references to the case is the emphasis upon Archer's responsibility for the dishonourable act of poisoning. It was Archer who advised Saunders 'to put an end to her life by poison'. ${ }^{91}$ It was also Archer who 'bought the poison, viz arsenick and roseacre, and delivered it to Saunders, who then gave it to his wife'. ${ }^{92}$ On this account, Archer is as wicked, if not more so, than Saunders.

In his notes, Plowden states: 'the poisoning of the daughter was a distinct fact, to which Archer gave no advice nor council, and whose death he did not procure'. ${ }^{93}$ Even in his approval of the acquittal, Plowden raises doubt as to Archer's lack of responsibility for the outcome by referring to the original act of poisoning. This argument also contradicts Plowden's reasoning:

But when he lays the poison with an intent to kill any reasonable creature, and another reasonable creature, whom he does not intend to kill, is

$\overline{90 \quad \text { Ibid, cap 7, } 52 \text {. }}$

$91 \quad R v$ Saunders and Archer (1573) 2 Plowden 473; 75 ER 706, 707.

92 Ibid.

93 Ibid, 711. 
poisoned by it, such death shall not be dispunishable, but he who prepared it shall be punished for it, because his intent was evil. ${ }^{94}$

Even if the identity of the victim had changed, Archer had still assisted with the crime - he had procured the poison with the intention of assisting in a homicide.

In addition, the acquittal of Archer, despite his procurement of poison, contradicts a historic and contemporary legal principle that where an accused had committed an original unlawful act, the accused would be held responsible for all the consequences. Saunders and Archer was often cited by treatise writers along with other examples of this kind of original unlawful act. For example, Hale listed Saunders and Archer under the heading of implied malice 'in relation to the person killing':

If A come to rob B in his house, or upon the highway, or otherwise, without any precedent intention of killing him, yet if in the attempt either without or upon resistance to $\mathrm{B}, \mathrm{A}$ kills $\mathrm{B}$, this is murder.

So if a sheriff have a precept to hang a man for felony, and he beheads him, it is murder.

To these may be added the cases abovementioned, viz. if A by malice forethought strikes at $\mathrm{B}$ and missing him strikes $\mathrm{C}$, whereof he dies, tho he never bore any malice to $\mathrm{C}$ yet it is murder, and the law transfers the malice to the party slain; the like of poisoning, sed de his supra cap..$^{95}$

In this use of Saunders and Archer, treatise writers drew upon biblical and social notions of wickedness. The attribution of malice due to an original disorderly act was an integral idea underlying the doctrine of implied malice:

Such as happens in the Execution of an unlawful Action, principally intended for some other Purpose, and not to do a personal Injury to him in particular who is slain, in which Case the Malice seems to be most properly to be implied. ${ }^{96}$

This construction of malice due to an original, disorderly or unlawful act appealed to religious notions of responsibility:

Do not be deceived: God cannot be mocked. A man reaps what he sows. The one who sows to please his sinful nature, from that nature will reap destruction; the one who sows to please the Spirit, from the Spirit will reap eternal life..$^{97}$

The underlying religious theme augmented this conception of wickedness and the idea that a person who behaved in a disorderly and/or unlawful way would be responsible for all outcomes.

Malice was manifest in the original breach or violation of cherished community values, whether expressed at law and/or assumed in society. ${ }^{98}$ Hawkins secularised this biblical expression of responsibility:

$94 \quad$ Ibid, 708

95 Hale, above n 17, 465-466.

96 Hawkins, above n 27, 80.

97 Galatians 6:7.

98 This idea remains relevant in contemporary criminal law. There is reason to believe that members of the general community regard killing during the course 
They must at their Peril abide the Event of their Actions, who wilfully engage in such bold Disturbances of the Publick Peace, in open Opposition to, and Defiance of, the Justice of the Nation. ${ }^{99}$

Treatise writers agreed in principle that an original unlawful act could manifest sufficient malice and that the accused would be blameworthy for any and all consequences.

Here again, there is discomfort about the reach of the criminal justice system. There were debates amongst treatise writers about the reach of the principle of constructive malice. There were differences of opinion amongst treatise writers about whether or not an original unlawful act was sufficiently blameworthy to justify a finding of murder for any resulting slaying, or if something more was needed, whether only a more serious offence or wicked intent could establish sufficient wickedness or malice for murder. ${ }^{100}$ For example, Coke defined felony murder very broadly, requiring only an unlawful act that caused death:

If the act be unlawful, it is murder. As if A meaning to steal a Deer in the park of B, shooteth at the Deer, and by the glance of the arrow killeth a boy that is hidden in the bush: this is murder for that the act was unlawful, although A had no intent to hurt the boy, nor knew of him. ${ }^{101}$

This assertion by Coke was widely influential but it was also subject to debate. ${ }^{102}$ It was this felony murder rule asserted by Coke that Stephen regarded as monstrous. ${ }^{103}$ This discomfort about the harsh reach of constructive malice was exacerbated due to the indirect involvement of Archer. The judges were reluctant to extend the already contentious principle of constructive malice to accessories. ${ }^{104}$

\section{Conclusion}

The case of Saunders and Archer provides an example of the implications of the penal and procedural identic turn. At the time Saunders and Archer

of a serious offence the most serious form of homicide: Barry Mitchell, 'Public Perceptions of Homicide and Criminal Justice' (1998) 38 British Journal of Criminology 453; Barry Mitchell, 'Further Evidence of the Relationship between Legal and Public Opinion on the Law of Homicide' [2000] Criminal Law Review 814.

99 Hawkins, above n 27, 84.

100 J Kaye, 'The Early History of Murder and Manslaughter: Part I' (1967) 83 Law Quarterly Review 365.

101 Coke, above n 15, cap 9, 56.

102 For example, Foster limited the unlawfulness requirement in felony murder to only those offences that were malum in se, that is, 'real' crimes: Foster, above n 6, 258.

103 These kinds of debates continue in modern law with arguments amongst theorists and differences across jurisdictions for the rules of constructive murder.

104 Contemporary complicity law has developed the doctrine of common purpose. If an accessory has agreed to aid, abet, counsel or procure one offence, but recognises the possibility that in furtherance of that offence, another offence may be committed, the accessory will be liable for that additional offence. See Johns $v$ The Queen (1980) 143 CLR 108. 
was decided, accessories were liable to the same punishment as principals. It was assumed that the identic turn could also be relied upon in justifications for attributions of blameworthiness - an accessory's liability could be explained and explored through the same models applied to the principal. However, my analysis of Saunders and Archer has highlighted the ways in which classic models of culpability do not fit easily when applied by the judiciary and treatise writers to accessories. Whilst Archer had an intention to assist in the slaying of Saunders' wife, he did not have the intention to do the act himself. Archer's procurement of the poison was instrumental in causing the death of Eleanor, regardless of his absence from the scene of the crime. The common law implicitly assumed (and assumes) a relationship between principal and accessorial liability, but failed (and fails) to articulate a coherent and persuasive story of their similarities and differences. The common law avoided (and avoids) conceptualising and engaging with the potential of the doctrine of complicity to challenge cherished legal assumptions of agency and autonomy in attributions of culpability, of both the principal and the accessory. The patterns of blameworthiness taken from principals and applied to accessories do not provide resolution to cases such as Saunders and Archer. Instead, the story of Archer's culpability is left unresolved. Archer's involvement is now misremembered and recorded as a case of withdrawal, even though withdrawal was not relevant to the case or considered by the judiciary. ${ }^{105}$ Plowden framed his report of the principles of the case in biblical terms of 'repentance', and this is how the case has been (mis)remembered. ${ }^{106}$ Even in this false memory of Archer's involvement, the boundaries of complicity remain unclear. Although the requirement of repentance remains, the authorities are inconclusive as to whether true moral repentance is necessary. ${ }^{107}$ Although heard in the 16th century, the issues raised in Archer's case are sustained in contemporary law. How similarly can and should the accomplices be treated to principals, in terms of procedure, punishment and underlying patterns of culpability?

105 See, for example, Smith, above n 11, 251; Ashworth and Horder, above n 35.

106 Hale, above n 17, 618; Hawkins, above n 27, ii, ch 29, s 16.

107 In Weaver $v$ State 42 SE 745, 747 (1902) the Court considered the reasons why an accused may have withdrawn from a crime: 'whether he was frightened by the approach of the officers or deterred by the voice of conscience and repented of his wicked intentions'. 